\title{
THE ESTABLISHMENT OF INTERNATIONAL MECHANISMS FOR ENFORCING PROVISIONAL ORDERS AND FINAL JUDGMENTS ARISING FROM SECURITIES LAW VIOLATIONS
}

\author{
Michael D. ManN, ${ }^{*}$ Paul A. Leder, ${ }^{* *}$ and Elizabeth Jacobs***
}

\section{INTRODUCTION}

In the last ten years, securities regulators have made substantial progress in developing cooperative relationships to reduce the value of international borders as barriers to the detection and prosecution of securities fraud. Having made that progress, attention now should turn to ensuring that those committing fraud will not only be caught and prosecuted, but also will be deprived of the financial fruits of their illegal activities.

Transactions on U.S. securities markets can originate virtually any place in the world. In order to carry out trades, one needs only a phone line and access to a wire transfer facility. Regulators, however, cannot cross borders with the same ease as the transactions they may need to investigate. While regulators have resolved many of the territorial and sovereignty issues that previously constrained their ability to investigate and pursue suspect foreign transactions, similar constraints hamper the freezing of assets and recovery of ill-gotten gains located in other jurisdictions. This article focusses on the development of mechanisms, similar to those used for information-sharing, pursuant to which regulators can assist each other in freezing assets and recovering illicit profits.

The Securities and Exchange Commission ("SEC") and many of its foreign counterparts have addressed territorial and sovereignty concerns by creating cooperative mechanisms for gathering and exchanging information for use in international investigations. These mechanisms, commonly referred to as Memoranda of Understanding ("MOUs"), effectively extend a regulator's investigative reach beyond its national boundaries. Thus, through

Copyright $(\odot) 1992$ by Law and Contemporary Problems

* Director, Office of International Affairs, Securities and Exchange Commission.

** Assistant Director, Office of International Affairs, Securities and Exchange Commission.

*** Senior Counsel, Office of International Affairs, Securities and Exchange Commission.

The SEC, as a matter of policy, disclaims responsibility for any private statement by any of its employees. The views expressed here are those of the authors and do not necessarily reflect the views of the SEC, or of the authors' colleagues on the staff of the SEC. 
MOUs, regulators are better able to investigate and prosecute successfully persons engaging in illegal transactions conducted in or affecting domestic securities markets that emanate from abroad. ${ }^{1}$ The ability to prosecute foreign-based fraud is only part of the challenge, however. In the end, success will be judged by whether those committing fraud can hide ill-gotten gains, thereby reaping the financial benefits of wrongdoing, or whether the funds will be recovered for the benefit of investors. The ability to recover assets also will enhance the value of the ties forged by regulators to fight cross-border fraud.

Effective enforcement of securities laws requires that regulators be able to thwart the dissipation or secreting of the fruits of international securities fraud, and to facilitate the return of the illicit profits to injured investors. ${ }^{2}$ In addition, as with cooperative mechanisms for information-gathering, the development of any mechanisms designed to facilitate the recovery of illgotten gains will enhance confidence in global securities markets and facilitate possible harmonization and mutual recognition of regulatory schemes. ${ }^{3}$

This article describes the current legal framework for executing judgments obtained by securities regulators and explores issues that have arisen in this context. Based on recent experiences in developing cooperative arrangements to resolve problems concerning international informationgathering, it concludes by proposing alternatives for resolving problems in executing securities judgments. ${ }^{4}$

1. Both an indication of, and source for, the success of the MOU approach is the growing unanimity among securities regulators in support of it. See, for example, Resolution Concerning Mutual Assistance with the International Organization of Securities Commissions ("IOSCO"), 43 SEC Docket 168 (Nov 7, 1986); Report Addressing the Difficulties Encountered with Negotiating and Implementing Memoranda of Understanding, approved at XVth Annual Conference of IOSCO, Santiago, Chile, 1990 ("Santiago Report"); Principles for Memoranda of Understanding, approved at XVIth Annual Conference of IOSCO, Washington, DC, 1991.

2. See International Capital Markets Group, Part III Paper on International Regulatory Issues (March 1991), prepared by the Federation Internationale des Bourses de Valeurs, with the assistance of the International Bar Association and the International Federation of Accountants:

Also of importance [in addition to agreement to share information] is authority for the global recognition of court judgments in order to, for example, reach foreign deposits of unlawful profits, or to recognize preliminary injunctions to freeze assets not within the jurisdiction of the court. The latter is important even though the court may have jurisdiction over the person with control over the account in question.

3. In the SEC's first multijurisdictional disclosure system, entered into with Canada, the SEC relied upon the MOU with Canadian regulators as one factor supporting the recognition of a foreign disclosure system. MOU between the SEC and the Ontario Securities Commission, the Commission des Valeurs Mobilieres du Quebec and the British Columbia Securities Commission, 43 SEC Docket 186 (Jan 7, 1988). See also Multijurisdictional Disclosure and Modifications to the Current Registration and Reporting System for Canadian Issuers, Securities Exchange Act of 1934 ("Exchange Act") Rel No 34-29354, 56 Fed Reg 30036 (July 1, 1991); Recognition of Foreign Broker-Dealer Regulation Release, Exchange Act Rel No 27018, 54 Fed Reg 30087 (July 11, 1989); Stabilizing to Facilitate a Distribution, Exchange Act Rel No 34-28732, 56 Fed Reg 814 (Jan 9, 1991); and Anant K. Sundaram, National Sovereignty to Blame for BCCI Scandal, Wall St J A17 col 3 (Oct 24, 1991). In his editorial, Sundaram urges the immediate convention of a General Agreement on Tariffs and Trade ("GATT") conference to resolve issues of regulatory disharmony among banking regulations as a way of avoiding future scandals. He notes that regulatory inconsistencies may exist due, among other reasons, to the lack of comprehensive mechanisms for cross-border enforcement of laws.

4. There is a distinction between recognizing a judgment and enforcing a judgment: 
II

\section{Enforcement of Judgments and Ancillary Provisional Remedies in Cases Initiated by the Securities and Exchange Commission}

It is well established that the SEC can seek, and U.S. courts can order, the disgorgement of proceeds illegally obtained as a result of federal securities law violations. ${ }^{5}$ The primary purposes of such orders are to deprive wrongdoers of unjust enrichment and to deter others from violating securities laws by taking the profit out of crime. ${ }^{6}$ In fiscal year 1990 , the SEC obtained court orders requiring defendants to disgorge the record amount of $\$ 589$ million, including $\$ 400$ million paid by Michael $R$. Milken. ${ }^{7}$ In addition to seeking disgorgement in civil actions, the SEC now has the power to order disgorgement in administrative proceedings. ${ }^{8}$ However, the right to request the disgorgement of illegal profits is meaningful only to the extent that such proceeds are identifiable and can be preserved. Accordingly, an important step toward the recovery of funds is the ability to seek asset-freezes. ${ }^{9}$ Absent such asset-freezes, the effectiveness of a final judgment commanding disgorgement may be undermined by a defendant dissipating or secreting the funds.

Currently, no comprehensive mechanism exists by which the SEC is able to enforce effectively final judgments and ancillary provisional relief outside the United States. ${ }^{10}$ This gap has reduced the SEC's efforts to recover illicit profits to a race to the border to prevent the illegal gains from leaving the jurisdiction of a U.S. court. ${ }^{11}$

\footnotetext{
A foreign judgment is recognized when a court concludes that a certain matter has been decided in the judgment and therefore will not be litigated further. A foreign judgment is enforced when a party is accorded part or all of the relief to which the judgment entitles him.
}

Robert B. von Mehren, Enforcement of Foreign Judgments in the United States, 17 Va J Intl L 401 (1977). 5. See, for example, SEC v First City Financial Corp., 890 F2d 1215 (DC Cir 1989); SEC v General Refractories Co., 400 F Supp 1248 (D DC 1975).

6. General Refractories Co., 400 F Supp 1248.

7. In 1991, the SEC obtained court orders for disgorgement of approximately $\$ 119$ million. See 1990 SEC Annual Report 1, 8.

8. Securities Enforcement Remedies and Penny Stock Reform Act of 1990, Pub L No 101-429, 104 Stat 931 (1990), codified at 15 USC $\S 78$ (a) (1989). See also Colleen P. Mahoney, A Summary of the Remedies Provisions of the Securities Enforcement Remedies and Penny Stock Reform Act of 1990 (Practising Law Inst, 1991).

9. See SEC v Manor Nursing Centers, Inc., 458 F2d 1082, 1106 (2d Cir 1972); SEC v Vaskevilch, 657 F Supp 312, 315 (SD NY 1987); SEC v Fondation Hai, 736 F Supp 465, 474 (SD NY 1990); SEC v Unifund SAL, 910 F2d 1028, 1041-43 (2d Cir 1990).

10. Indeed, even for private litigants there are obstacles and difficulties to obtaining recognition of U.S. provisional judgments. See Restatement (Third) of Foreign Relations Law of the United States \$ 481 (1987) ("Judgments granting injunctions ... are not generally entitled to enforcement ...."). See also von Mehren, $17 \mathrm{Va} J$ Intl $\mathrm{L}$ at $406 \mathrm{n} 25$ (cited in note 4) (citing the New York State Bar Association Report and Proposed Resolution of Committee on International Law: "nonrecognition of United States' judgments abroad is the rule rather than the exception . . ...); Charles Platto, ed, Enforcement of Foreign Judgments Worldwide (Graham \& Trotman, 1989).

11. While U.S. courts may exercise subject matter jurisdiction when significant conduct occurs in the United States or when it occurs outside the United States but has a significant effect within the United States or on the interests of U.S. investors, see, for example, Bersch v Drexel Firestone, Inc., 519 


\section{A. SEC v. Wang and Lee}

In SEC $v$. Wang and Lee, ${ }^{12}$ the SEC alleged that Stephen Wang, an employee of a New York investment banking firm, stole "inside" information and provided it to Fred C. Lee, a Taiwanese national, for trading purposes, and that Lee traded on the information through a series of nominee accounts in the United States and overseas. The SEC filed a civil action, as described more fully below. Among other things, the SEC requested that the U.S. district court order a U.S. branch of a Hong Kong bank with which Lee maintained accounts to pay monies controlled by Lee into the U.S. court registry. The SEC's actions to ensure the preservation of Lee's assets raised concerns in the international banking community about the validity of the separate entity doctrine, under which each branch of a bank is treated as a juridical entity separate from the parent. ${ }^{13}$

Prior to the initiation of the civil suit, Lee agreed to testify in Hong Kong in connection with the SEC's investigation. While under oath, Lee initially denied trading on material nonpublic information. Lee then abruptly sought to withdraw this testimony and, through counsel, admitted that he had illegally purchased securities on the U.S. markets. This recantation took place on June 24, 1988, the same day Lee instructed certain banks and brokerage firms in the United States to transfer funds representing his liquid assets to Hong Kong. ${ }^{14}$ In response to Lee's efforts to move assets outside the United States, on June 27, 1988 the SEC filed an action against Wang and Lee and made an ex parte application for a temporary restraining order ("TRO") that included an asset-freeze provision. The SEC argued that expedited action was necessary in light of Lee's ongoing attempts to remove his illicit profits from the United States. Later that day, the court granted the TRO, which included a freeze of all Lee's assets. The TRO was then served on all known holders of Lee's assets, including Standard Chartered Bank ("SCB"), a British bank with branch offices in Hong Kong and New York.

F2d 974, 987-92 (2d Cir 1975); Leasco Data Processing Equipment Corp. v Maxwell, 468 F2d 1326, 1333 (2d Cir 1972); Schoenbaum v Firstbrook, 405 F2d 200, 206-07 (2d Cir), rev'd on other grounds, 405 F2d 215 (2d Cir 1968) (en banc); Alfadda v Fenn, 935 F2d 475, 478 (2d Cir 1991), enforcement power is effectively limited to those persons over whom the courts have personal jurisdiction. See Bersch, 519 F2d at 999-1000; Leasco, 468 F2d at 1341-42; Fondation Hai, $736 \mathrm{~F}$ Supp at 469. Thus, where the fruits of fraud are removed from the United States and the wrongdoer who controls those fruits is in a foreign country, the U.S. court may be left without means of enforcing relief.

12. Litigation Rel No 11780 [1987-1988 Transfer Binder] Fed Secur L Rptr (CCH) ๆ 93,802 (SD NY 1988).

13. The separate entity doctrine dates from the eighteenth and nineteenth centuries and was designed to protect banks from having multiple withdrawals made for the same funds from different branches of the same bank. See, for example, Patrick Heininger, Liability of U.S. Banks For Deposits Placed in their Foreign Branches, 11 L \& Pol Intl Bus 903, 907, 930-44 (1979). Today, in light of highspeed electronic communications between even the most far-flung offices, that rationale for the doctrine has been substantially weakened.

14. On that same day, Lee's counsel also admitted to the SEC that Lee was already attempting to transfer funds out of the United States to Hong Kong, that Lee would continue those efforts, and that he would continue to trade in the U.S. securities markets. See Declaration of Gary S. Kaminsky [counsel for the SEC] in Support of Plaintiff's Ex Parte Application for Temporary Restraining Order and Other Related Matters. 
Almost immediately after the issuance of the TRO, Lee violated the order by demanding that $S C B$ release to him funds that represented the profits of his illegal trading and by threatening to sue SCB if it failed to comply with his demand. Upon learning of Lee's actions in Hong Kong, the SEC sought, and the U.S. district court ordered, an injunction against Lee filing suit, other than in the Southern District of New York, relating to his assets ("anti-suit injunction"). Based on SCB's continued refusal to comply with Lee's demand for payment, Lee brought an action in Hong Kong against SCB, and applied to the Supreme Court of Hong Kong for a declaration that the U.S. order freezing his assets did not restrain SCB from complying with his demands for payment.

In light of Lee's open defiance of its orders, including the anti-suit injunction, upon the motion by the SEC, the U.S. district court held a hearing to decide whether SCB's New York branch should be required to pay Lee's allegedly ill-gotten gains into the U.S. court registry. The SEC argued that it was necessary to sequester the funds in the registry to protect the investors allegedly defrauded in the insider trading scheme. SCB contended that the court had no jurisdiction to require the payment of funds held in its Hong Kong branch. The court held that it had jurisdiction over Lee, who had traded in the United States and had been served with the SEC's summons and complaint, and that the funds in question represented Lee's illicit profits. Accordingly, the court issued an order on August 11, 1988, directing SCB to pay monies into the registry of the court from accounts controlled by Lee ("sequestration order"). SCB complied with the order but filed a notice of appeal.

Lee continued to press his claims against SCB in the Hong Kong Supreme Court. On September 22, 1988, the Hong Kong court, after a hearing on the matter, issued an order denying Lee's application for a declaratory order against SCB. ${ }^{15}$ Following a line of reasoning offered by the bank, the Hong Kong court concluded that SCB might be holding the funds as a constructive trustee for the benefit of investors defrauded by Wang and Lee, that such investors were the beneficial owners of the funds, and that Lee's companies were, therefore, not entitled to delivery of the funds.

In light of the Hong Kong court's decision that the funds appeared to be beneficially owned by investors, SCB's arguments on appeal appeared hollow. Nonetheless, SCB argued that because the Hong Kong court did not fully recognize the effect of the U.S. court order, but instead recognized the possibility of a constructive trust, the U.S. court's sequestration order in effect subjected the bank to double liability, under which it could be required to make payments both in Hong Kong and New York. Accordingly, SCB and

15. See Nanus Asia Co., Inc. v SCB, Misc Proc No 1459 (S Ct Hong Kong Sept 22, 1988); Southridge Intl. Inc. v SCB, Misc Proc No 1460 (S Ct Hong Kong Sept 22, 1988). According to the SEC, the plaintiffs in the related actions were Lee's corporate alter egos. See Brief of SEC (Appellee), Civ Nos 88-6236, 6316 (May 1989). 
amicil6 contended that the order was an unconstitutional attachment or garnishment of SCB's own funds, running afoul of international law and upsetting settled practices of the international banking community. In particular, SCB alleged that the U.S. district court order violated the separate entity doctrine ${ }^{17}$ because the order ran to a different branch than the one at which the subject account was opened. Finally, SCB challenged the U.S. district court's authority to issue a garnishment order that, in SCB's view, garnished a debt localized in Hong Kong. ${ }^{18}$

In opposition, the SEC argued that the order did not impose any risk of double liability because it was in the nature of an equitable sequestration, which did not impose a lien on the sequestered property or affect its title. The SEC further argued that the district court did not garnish property, but rather issued in personam orders to the person controlling the money, $\mathrm{Mr}$. Lee, which were necessary under the facts presented to give full effect to a final decree. Citing United States $v$. First National City Bank, ${ }^{19}$ the SEC argued that such in personam orders were within the scope of the court's equitable jurisdiction in government enforcement actions. The SEC also contended that, when viewed properly, the order did not impermissibly infringe on Hong Kong sovereignty, violate international law, or upset settled practices of the international banking community, because the subjects of the order were $\mathrm{Mr}$. Lee and the bank's New York branch, both of whom had control over the funds in question, and over whom the court had personal jurisdiction. ${ }^{20}$ The U.S. appellate court never had an opportunity to rule on these issues. In

16. The amici included the United Kingdom, the Federal Reserve Bank of New York, the New York Clearing House Association, and the Institute of International Bankers and Foreign Bankers' Association. Brief of the Appeal of the Government of the United Kingdom of Great Britain and Northern Ireland as Amicus Curiae, SEC v Wang, 699 F Supp 44 (SD NY 1988), appeal docketed, Nos 88-6236, 88-6316 (2d Cir May 27, 1989); Brief of the Federal Reserve Bank of New York as Amici Curiae, SEC v Wang, 699 F Supp 44 (SD NY 1988), appeal docketed, Nos 88-6236, 88-6316 (2d Cir May 27, 1989); Brief of the New York Clearing House Association, The Institute of International Bankers and Foreign Bankers Associations as Amici Curiae, SEC v Wang, 699 F Supp 44 (SD NY 1988), appeal docketed, Nos 88-6236, 88-6316 (2d Cir May 27, 1989).

17. See note 13.

18. While the order was on appeal, the SEC filed a motion for remand, or, alternatively, for supplementation of the record, based on documents, including account-opening agreements, that were produced by SCB after the district court's ruling. The SEC asserted that the documents demonstrated that Lee had the right to make withdrawals from any SCB branch, including New York. Therefore, the SEC argued, SCB's assertion that the bank account at issue was in Hong Kong and its concerns about the extraterritorial effect of the U.S. district court's order were without foundation. The SEC further asserted that the documents provided evidence pertaining to the authority of the U.S. court to affect the SCB accounts and that a remand was necessary to permit further discovery and the entry of additional findings by the district court. SEC Motion for Remand, or alternatively for Supplementation of the Record, SEC v Wang, 699 F Supp 44 (SD NY 1988). In an order dated April 13, 1989, a motions panel of the U.S. Court of Appeals for the Second Circuit denied the SEC's motion, concluding that remand was inappropriate, prior to the bank's opportunity to argue the merits of its appeal. The court further noted that after the appeal was heard, the merits panel would be in a better position to decide whether to affirm or reverse on the existing record or remand for further proceedings.

19. 379 US 378, 383 (1965).

20. With respect to certain funds that Lee attempted to transfer outside the United States immediately prior to the time the SEC obtained the freeze order, the SEC argued that it was in "hot pursuit" of these funds, and its ability to preserve assets should not be thwarted by the fortuity of the 
August 1989, while the appeal was pending, Lee consented to the entry of a Final Judgment of Permanent Injunction, which included his surrender of $\$ 25,150,000 .{ }^{21}$ On August 2, 1989, SCB and the SEC jointly moved for voluntary dismissal of SCB's appeal; the Second Circuit granted the parties' motion. Due to Lee's settlement, the legal issues raised by Wang and Lee remain unresolved. At this point, Wang and Lee illustrates an important method that, in the absence of better alternatives, the SEC has used, and will continue to use, to safeguard illicit profits within the jurisdiction of U.S. courts until they can be returned to defrauded investors. The controversy caused by the SEC's action in Wang and Lee also serves notice for the need to develop the alternatives necessary to obtain similar results-the effective freezing of a defendant's assets-while avoiding both the cost and uncertainty of such case-by-case litigation.

\section{B. SEC v. Fondation Hai and SEC v. Unifund SAL}

Market surveillance is conducted on a real-time basis; U.S. self-regulatory organizations and the SEC can detect questionable trading almost instantly. ${ }^{22}$ As a result, the SEC increasingly is aware of suspicious trading even before the initial purchase transactions are cleared and, in insider trading cases, often before the material event has been announced. In more recent cases, this information has allowed the SEC to move quickly to freeze assets and securities while they are still in the hands of U.S. brokerage firms, thus avoiding the issues that arose in Wang and Lee. Such decisive action, however, has raised new problems in cases where exigencies do not allow for a complete investigation prior to seeking that assets be frozen. In particular, the need to complement domestic freeze orders with assistance from foreign authorities illustrated by Wang and Lee is evidenced further by difficulties that arose in SEC v. Fondation $\mathrm{Hai}^{23}$ and SEC v. Unifund SAL. ${ }^{24}$ In Fondation Hai, the U.S. district court froze trading assets of foreign defendants within hours of when the suspicious purchases were made. The defendants included Lebanese and Panamanian entities and certain unknown persons, including some who traded through Swiss bank accounts, who had purchased shares of the Rorer Group, Inc., a U.S. company, prior to the public announcement of Rorer's acquisition by Rhone-Poulenc, S.A., a French corporation. There had been massive trading in Rorer securities prior to the public announcement of the potential acquisition on January 15 . On January 10 and 11 , the volume of options traded doubled from the prior day, and on January 12 was nearly ten

timing of a bank transfer in relation to a freeze order. See Brief of SEC (Appellee), Civ Nos 88-6236, 88-6316 (May 1989).

21. The total included approximately $\$ 19$ million in alleged illicit profits. These funds are in the process of being distributed to investors. See SEC v Wang, 944 F2d 80, 82 (2d Cir 1991) (affirming approval of plan for distribution of disgorged funds).

22. Hearing before the Commerce, Consumer and Monetary Affairs Subcommittee of the House Committee on Government Operations, 100th Cong, 2d Sess 259 (1988) ("Barnard Report").

23. 736 F Supp 465 (SD NY 1990).

24. 910 F2d 1028 (2d Cir 1990). 
times the average daily volume in the prior month. Moreover, the volume of shares traded on January 12 was six times the average daily volume of the previous twenty days. Several defendants' purchases vastly exceeded securities purchases that they had made previously. ${ }^{25}$ The U.S. district court granted the SEC's application for provisional relief, including freeze orders. Two defendants appealed from the court's entry of preliminary injunctions. The Second Circuit affirmed, with modifications, the district court's freeze orders, directing, however, that the modified freeze orders terminate thirty days after the issuance of its mandate unless the SEC proceeded to trial.

In a petition for rehearing, the SEC argued that an injunction freezing the defendant's assets should be maintained until all reasonable discovery was completed. ${ }^{26}$ The SEC highlighted the difficulties and delays inherent in obtaining evidence from foreign jurisdictions, ${ }^{27}$ and argued that the Second Circuit's limitation on the duration of the freeze order would deprive the SEC of a fair opportunity to make a definite showing of likelihood of success on the merits prior to expiration of the freeze. The SEC also stated that such a limited-duration freeze might seriously hamper effective prosecution of international insider trading cases, and could undermine international enforcement cooperation. In this regard, the SEC filed an affidavit outlining the extensive efforts it had undertaken, and that were still pending, to obtain evidence. In particular, the SEC had made several requests to France under the Hague Convention on the Taking of Evidence Abroad in Civil and Commercial Matters ("Hague Evidence Convention"),, 28 as well as requests to Switzerland pursuant to a criminal mutual legal assistance treaty ("MLAT"). ${ }^{29}$ The petition for a rehearing was denied. ${ }^{30}$

Although the SEC, with the assistance of French and Swiss authorities, was able to gather substantial evidence abroad, it was unable to complete foreignbased discovery in the thirty-day time frame established by the Second Circuit. Consequently, the SEC did not have the opportunity to make a

25. See SEC's Memorandum in Support of a Motion for (1) Preliminary Injunction, (2) An Order Freezing Assets, and (3) An Order Preventing Alteration or Destruction of Documents. $90 \mathrm{Civ}$ 0277 (Feb 10, 1990) (SWK).

26. The SEC argued that the freeze order should be extended based upon a showing that there existed "serious questions of fact or law going to the merits so as to make a fair ground for litigation"- a standard for injunctive relief that is available in private litigation as long as the plaintiff can show irreparable injury. See, for example, Hamilton Watch Co. $v$ Benrus Watch Co., 206 F2d 738, 740 (2d Cir 1953). The court, noting that the SEC is not required to show irreparable injury, held the SEC to the higher standard of a "likelihood of success on the merits." Court Order (Aug 3, 1990):

27. In support of its motion, the SEC filed affidavits of the U.S. Department of Justice, the U.S. State Department, and the Swiss Federal Office for Police Matters, which is the Swiss authority responsible for implementing the criminal mutual legal assistance treaty between the United States and Switzerland. The affidavits all noted the delays inherent in obtaining foreign-based evidence and that the imposition of unreasonable discovery deadlines in these types of cases could have deleterious effects on achieving international cooperation. Exhibits to Petition of SEC (appellee) for Rehearing as to Duration of Freeze Orders, Civ Nos 90-6057, 6091, 6093, 6103 (Aug 3, 1990).

28. [1972] 23 UST 2555, TIAS No 7444 (1970).

29. Treaty on Mutual Assistance in Criminal Matters between the Untied States and Switzerland, [1976] 27 UST 2019, TIAS No 8302 (1977).

30. Denied by Court Order, Oct 23, 1990. 
definite showing of likelihood of success on the merits. As a result, prior to the completion of foreign discovery, the court released approximately $\$ 2$ million of one defendant's assets that had been frozen at a U.S. brokerage firm. ${ }^{31}$

Fondation Hai has complicated the SEC's task of preserving ill-gotten gains while it pursues complex international frauds. ${ }^{32}$ When considered in conjunction with the issues raised in Wang and Lee, absent a change in the standard for freeze orders in the United States, the need to develop avenues for assisting foreign regulators is all the more apparent.

\section{SEC v. Antar}

The Antar case illustrates problems that can arise when an alleged securities law violator flees the United States with his assets to avoid the execution of a judgment. The success that the SEC ultimately had in finding and blocking Antar's ill-gotten gains demonstrates the importance of developing and enhancing arrangements for the execution of judgments.

In 1990, the SEC sued Eddie Antar, the founder and former Chairman, President, and Chief Executive Officer of Crazy Eddies, Inc. The SEC alleged, among other things, that he defrauded investors by fraudulently

31. Fondation Hai may make it more difficult to maintain asset freezes in the United States in cases involving protracted foreign discovery because it may allow foreign defendants to control the timing of when a case goes to trial. In other recent cases described below, foreign defendants have refused to identify themselves or otherwise appear absent the SEC's use of international agreements to learn their identities. In response, the SEC has sought default judgments against such defendants, while continuing to pursue their identities under foreign information-sharing agreements. This approach ensures that the defendant who chooses to frustrate SEC efforts to litigate a case by staying outside the U.S. jurisdiction cannot control the timing for his entry of an appearance.

In 1991, the SEC obtained default judgments in two cases involving foreign-based insider trading, where the disgorgement of over $\$ 3$ million was ordered. SEC v Finacor Anstalt, and Certain Purchasers of Call Options for the Common Stock of Combustion Engineering, Inc., [1991 Transfer Binder] Fed Secur L Rptr ๆ 96,272 (SD NY 1991) (default judgments obtained against unknown purchasers trading through banks in the Cayman Islands and Luxembourg); SEC v Heider, [1990-1991 Transfer Binder] Fed Secur L Rptr ף 95,651 (SD NY 1990). The SEC was successful in identifying the unknown purchasers who traded through foreign bank accounts and later named those purchasers as defendants in the SEC action. See, for example, SEC v Norgren, 89 Civ 7667 (IMC), Litigation Rel No 13410 (Oct 15, 1992). In Heider, the SEC obtained default judgments against certain foreign defendants trading through accounts in Switzerland, Germany, and Luxembourg in the securities of Contel Corporation ("Contel") prior to the July 12, 1990 public announcement of an intended merger between Contel and GTE Corporation. The SEC detected unusually heavy trading in the securities of Contel during the days preceding the merger announcement, and the SEC filed a civil injunctive action the day after the merger announcement. Some of the unknown purchasers bought Contel securities through Swiss banks that, citing Swiss secrecy laws, refused to identify their customers. Rather than identify themselves and defend the action, some of these defendants had attempted to delay the processing of the SEC's request for assistance to the Swiss government, and the SEC obtained a default judgment as to those defendants. See Michael D. Mann \& Lise A. Lustgarten, Internationalization of Insider Trading Enforcement-A Guide to Regulation and Cooperation 17-18 (American Bar Association, 1991).

32. One paper notes that, in the event Fondation Hai affects the SEC's ability to seek expedited judicial relief in the United States against perceived violations of U.S. insider trading laws, the SEC will need to rely more heavily upon cooperation from foreign authorities to assist in the enforcement of U.S. securities laws. See Gary G. Lynch \& Sheila W. Sawyer, SEC Injunctive Actions Against Unknown Purchasers in Insider Trading Cases 16 (Oct 12, 1990) (paper presented at the Twenty-Third Annual Rocky Mountain State, Federal and Provincial Securities Conference). 
misrepresenting the financial condition of the company and engaging in insider trading. ${ }^{33}$ Prior to the issuance of a final judgment against Antar, the U.S. court ordered that he repatriate trading profits of over $\$ 52$ million, which had previously been transferred to Israel. Antar chose to flee the U.S. instead, depriving the court, for the time being, of any direct method to force him to repatriate his ill-gotten gains. ${ }^{34}$ Shortly thereafter, the court entered a judgment of over $\$ 70$ million against Antar, and appointed a trustee-receiver to take possession of all of Antar's property.

To gather information to determine a means to enforce the U.S. court's judgment, the SEC requested from Israel, under the Hague Convention, information concerning Antar's initial transfer to Israel. Based on the responses from Israel, the SEC learned that some of the profits had been transferred to Switzerland. The SEC, through the U.S. Justice Department, then made requests to Switzerland pursuant to the Swiss treaty. ${ }^{35}$ In connection with the Swiss Treaty request, a substantial amount of Antar's illegal profits were frozen at Swiss banks.

The case could be considered a success at this point to the extent that, through the use of the information obtained under the Hague Evidence Convention and the Swiss Treaty, Antar was deprived of the use of those funds. Because the Swiss freeze denied Antar access to the money, it forced him to come forward. Antar, using one of his false names, personally visited the Swiss authorities in an effort to convince them to release his money. That move by Antar proved his undoing. ${ }^{36}$ Using information obtained from the Swiss authorities, Antar was located and on June 24, 1992, at the request of U.S. authorities, Antar was arrested in Israel. ${ }^{37}$ Thereafter, the SEC obtained hundreds of documents Antar possessed at the time of his arrest. ${ }^{38}$ The documents revealed the location of some of Antar's assets and some of the

33. In the 1980s, Crazy Eddie was the largest retail electronics chain in the New York City area. See SEC v Antar, Litigation Rel No 12548 [1990 Transfer Binder] Fed Secur L Rptr (CCH) ף 95,341 (D NJ 1990).

34. Antar was also the subject of a criminal investigation. In the summer of 1992, a grand jury in New Jersey handed down an indictment charging Antar with, among other things, fraudulently inflating Crazy Eddie's inventory, making false filings with the SEC, and obstruction of justice. See Press Release, U.S. Attorney's Office for the District of New Jersey (June 24, 1992). A superseding indictment, which included charges under the Racketeer Influenced and Corrupt Organizations Law, 18 U.S.C. $\$ \S 1961-1968$ (1988), was issued in August 1992. See Proceedings Allowed to Begin in Jerusalem on Antar Extradition, Wall St J A16 col 2 (Aug 25, 1992).

35. As described on pages 323-24, the treaties may provide a mechanism for certain illegally obtained proceeds to be frozen.

36. Barry Meier, Crazy Eddie's Insane Odyssey, NY Times Cl col 5 (July 19, 1992)

37. Michael Roem, Crazy Eddie nabbed in Yaune by Police, Jerusalem Post 1 sec 3 col 2 (June 25, 1992).

38. Upon the motion of the SEC, the U.S. district court issued a Hague Evidence request to Israel for access to the documents seized by the Israeli police. In Israel, Antar objected to the processing of the Hague Evidence request. He argued that the Hague Evidence Convention was preempted by the U.S.-Israel extradition treaty and that the Hague Evidence Convention was impermissibly used to enforce a judgment. See Hague Evidence Convention, art 1 (cited in note 28).

Antar claimed that because a final judgment had been issued in the United States, the judicial proceedings in the United States had been completed. Therefore, the information sought was not in connection with a "judicial proceeding commenced or contemplated," and the request should be rejected. In addition, Antar argued that the request for information was impermissible because it 
aliases under which they were kept. By making requests to its counterparts in other countries, ${ }^{39}$ the SEC was able to locate and freeze millions of dollars before Antar was able to dissipate them. In addition, the SEC or the U.S. court-appointed trustee-receiver has filed actions to enforce the final judgment against Antar, such as in Israel. ${ }^{40}$

As of the writing of this article, the case against Antar and recovery of his assets is still developing. Information-sharing mechanisms played a key role in identifying and tracking Antar's illegally obtained assets. Through use of ad hoc efforts, the SEC was able to piece together a net to prevent the dissipation of these assets. Had comprehensive arrangements to enforce judgments been in place, these efforts would have been both simplified and made more certain. Most importantly, they would have provided the SEC with a needed edge in the race to control illegally obtained assets.

\section{United Kingdom Cases}

The SEC is not alone in its ability or commitment to utilize unilateral measures to enforce final or ancillary provisional measures in connection with securities cases. For example, securities authorities in the United Kingdom have the power to seek provisional court orders where necessary to preserve assets for return to investors. ${ }^{41}$ In addition, U.K. courts have similarly faced issues involving the extraterritorial enforcement of court orders designed to

was being sought for a judicial act-the issuance of process by which judgments or orders are executed-that was expressly excluded from the scope of the Hague Evidence Convention.

The SEC argued that the matter was still pending before the U.S. courts to the extent the U.S. judge had jurisdiction to determine whether further relief should be granted against Antar or others, and to the extent the court-appointed trustee/receiver had equitable jurisdiction to recover Antar's assets. In addition, the request to the Israeli court was for information and evidence only; the U.S. court was not requesting the execution of the judgment against Antar under the Hague Evidence Convention.

On August 5, 1992, Judge Miriam Divon of the Magistrates Court of Tel Aviv rejected Antar's claims. In her opinion she agreed with the SEC's position that U.S. proceedings were still pending to the extent that the U.S. court retained jurisdiction to implement the judgment and a receivership, and therefore it was appropriate to seek the information under the Hague Evidence Convention. See The Applicant Judicial Authority, United States District Court, District of New Jersey, USA v Eddie Antar, Magistrates Court of Tel Aviv, Judge M. Dixon (Aug 5, 1992). Note that Antar had sought a stay of execution of the order, pending the filing of an appeal. The judge also denied this request, stating that "Every day and every hour is important to prevent Eddie Antar or his representatives ... from effecting an operation that would frustrate the application of the American Securities and Exchange Commission to place its hands on the money and property under Eddie Antar's control." The SEC was granted access to the seized documents while Antar's objections were pending.

39. Although all of these efforts have not yet been identified publicly, it has been reported that the Commission des Valuers Mobilieres du Quebec imposed a freeze on Antar's accounts in Canada for over $\$ 1$ million pursuant to an SEC request for assistance under the Canadian MOU. This was the first time that the SEC had sought a freeze of accounts under the MOU. In addition, the Commission des Operations de Bourse of France provided the SEC with assistance in obtaining documents and assets located in France that had been maintained at French banks in the name of Antar's wife. See SEC's Memorandum in Opposition to Eddie Antar's Motion to Vacate the Final Judgment (Nov'9, 1992).

40. Unlike Wang and Lee, the SEC already had secured a final judgment against Antar when it sought to freeze and recover illegal proceeds.

41. See Financial Services Act ("FSA") 1986 ch II, \$61 (i) (Eng.). Securities authorities in France also have the power to seek provisional court orders to preserve assets for the benefit of investors. See Law No 89-531 8-1, art 12-2 (1989) (Fr). The Commission des Operations de Bourse 
preserve assets for return to defrauded investors. Moreover, the United Kingdom approach has likewise been criticized because of the uncertainties created by attempts to hold entities that are within the jurisdiction of the court responsible for ill-gotten gains located outside of the country. ${ }^{42}$ Nonetheless, the U.K. courts have also recognized that, in the absence of a better mechanism, it is crucial for a court with jurisdiction over the matter to act to preserve the availability of relief.

U.K. courts have granted applications for extraterritorial Mareva injunctions (ex parte provisional relief orders) ${ }^{43}$ to the United Kingdom's Securities and Investments Board ("SIB").44 For example, in SIB v. Pantell, $S . A .{ }^{45}$ the SIB was granted a Mareva injunction in connection with an action commenced under Section 61(i) of the Financial Services Act ("FSA"), 46 restraining the defendant, a company registered in Switzerland, and its parent company, from dissipating any of their assets within the jurisdiction of the court or in the Channel Islands. ${ }^{47}$ U.K. authorities had begun investigating Pantell for, among other things, conducting an unauthorized investment business in the United Kingdom, and had discussions with Pantell's counsel, in which counsel admitted that Pantell's activities violated U.K. law and stated that Pantell would cease its activities in the United Kingdom.

Swiss authorities then informed U.K. authorities that the Swiss planned to close down Pantell because of violations of Swiss law, and that they had discovered that Pantell had obtained funds from, and done business with, U.K. investors. Furthermore, Swiss authorities disclosed that they had traced some of Pantell's assets to Barclays Bank in the United Kingdom. The SIB

("COB") also has the power to ask that a judge take protective measures on behalf of a foreign securities authority. See Santiago Report at 18 (cited in note 1).

42. See, for example, Ali Malek and Caroline Lewis, Worldwide Mareva Injunctions: The Position of International Banks, Lloyd's Marit and Comm L Q 88 (Feb 1990).

43. See Albert V. Dicey \& John H.C. Morris, Dicey and Morris on The Conflict of Laws 192-94 (Stevens \& Sons, 1 th ed 1987). See also Lawrence Collins, The Territorial Reach of Mareva Injunctions, 105 L Q Rev 262 (1989).

44. The SIB was the first self-regulatory organization ("SRO") designated by the United Kingdom's Department of Trade and Industry ("DTI") under the Financial Services Act ("FSA").

45. High Court of Justice, Chancery Division (Mar 8, 1989).

46. Section 61 (i) of the FSA provides among other things:

(1) If on the application of the Secretary of State the court is satisfied-

(a) that there is a reasonable likelihood that any person will contravene [specific provisions of the FSA or of the rules of certain SROs or similar professional bodies];

(b) that any person has contravened [such provision and rules] and that there is a reasonable likelihood that the contravention will continue or be repeated; or

(c) that any person has contravened any such provision or condition and that there are steps that could be taken for remedying the contravention,

the court may grant an injunction restraining the contravention ... as the case may be, make an order requiring that person and any other person who appears to the court to have been knowingly concerned in the contravention to take such steps as the court may direct to remedy it.

FSA ch II, $\S 61(\mathrm{i})$.

47. The Channel Islands are located off the southern coast of England. They are not a part of the United Kingdom, nor are they sovereign states or colonies. They have their own legislatures, judiciary, and executives, but the United Kingdom is responsible for their defense and international relations. 
then learned that Pantell had given Barclays Bank standing orders to transfer assets from the U.K. branch to an affiliate account in Guernsey Island. ${ }^{48}$

The SIB brought an action under the FSA to ensure that Pantell's assets would not be dissipated before the court rendered a final determination of whether Pantell had conducted an unauthorized investment business in the United Kingdom. Previously, Mareva injunctions had been granted only to individuals suing under a private right of action. ${ }^{49}$ In Pantell, the U.K. court concluded that Section 61 of the FSA conferred upon the SIB a statutory right of action for the benefit of investors, including the right to obtain Mareva relief to prevent a defendant from dissipating assets.

Pursuant to a court's order in issuing a Mareva injunction, a U.K. bank, having received service of the order, is required to ensure that funds held at other branches of the bank, wherever located, are not dissipated.50 Therefore, similar to the U.S. court's order in Wang and Lee, the U.K. court's order in Pantell explicitly blocked the defendant's assets held in branches of U.K. banks outside of the United Kingdom. Again, as with Wang and Lee, commentators have argued that subjecting banks within the jurisdiction of the court to this type of duty creates uncertainty and may expose banks to double liability. ${ }^{51}$

Wang and Lee and Pantell illustrate that the SEC, SIB, and other securities authorities will use aggressive means to block and obtain the ill-gotten gains of securities law violators, even when an international embroglio can arise where circumstances dictate that action must be taken on a unilateral basis. Fondation Hai and Antar demonstrate, however, that judicial unwillingness to freeze assets for a sufficient period of time, or the surreptitious actions of a defendant, can frustrate the recovery of funds for the benefit of defrauded investors.

48. Guernsey Island is one of the Channel Islands.

49. See generally Collins, $105 \mathrm{~L}$ Q Rev 262 (cited in note 43).

50. As more fully described in Collins, id, U.K. courts previously had excluded third parties from the operation of an order affecting foreign assets based on the theory that it was improper to subject acts taken abroad to actions for contempt. See Babanaft Intl. Co. S.A. v Bassatne, [1989] 2 WLR 232. In Pantell, however, the court adopted the proviso in Derby $E$ Co. Ltd. $v$ Weldon (Nos 3 and 4 ), [1989] 2 WLR 412, which states that to the extent the court order purported to have an extraterritorial effect, no person shall

be affected ... or concerned with the terms thereof until it shall be declared enforceable or be enforced by a foreign court . . . unless that person is . . . subject to the jurisdiction of this court and who: (i) had been given written notice of the this order . . . within the jurisdiction; and (ii) is able to prevent acts or omissions outside the jurisdiction of this court which assist in the breach of the terms of this order.

Derby $\mathcal{E}^{2}$ Co., Ltd., [1989] 2 WLR at 429. Collins notes that this proviso may have been drafted, in part, to "give a justification to an English bank which might wish to support the court in its efforts to prevent the defendant from frustrating the due course of justice." Collins, $105 \mathrm{~L} \mathrm{Q} \mathrm{Rev} \mathrm{at} 285$ (cited in note 43 ).

51. See notes 15-18 and accompanying text. See Malek \& Lewis, Lloyd's Marit \& Comm L Q at 96-98 (cited in note 42). Note, however, that dicta in other U.K. court cases support the concept that there may be a "hot pursuit" exception to potential infringements of sovereignty created by Mareva injunctions. See London and Counties Securities (in liquidation) $v$ Caplan (1978) (unreported) (discussed in Malek \& Lewis, Lloyd's Marit \& Comm L Q at 94 (cited in note 42)); Mackinnon v Donaldson, Lufkin and Jenrette Securities Corp., [1986] ch 482 (discussed in Collins, 105 L Q Rev at 285 (cited in note 43)). 


\section{III}

\section{Cooperation as an Alternative to Confrontation}

Currently there are no established international means for a securities enforcement agency to ensure that an asset freeze will be honored by persons and entities located outside of their jurisdiction. Since funds and securities can be moved with relative ease, either physically or electronically, this gap in the effectiveness of asset freezes is a dangerous one. However, satisfactory cooperative means can be developed to fill that gap and thereby avoid a repetition of the events that led to the sequestration order in Wang and Lee.

Impetus for the SEC's development of MOUs on the exchange of information was generated by the international community's desire to avoid the high-speed jurisdictional collisions caused by unilateral orders for the production of foreign based information. An examination of the process that generated the development of the first MOU between the United States and Switzerland, as well as those that have followed, reveals an important model for constructing alternatives for effectively freezing assets and executing final judgments abroad.

\section{A. Pre-MOU Cases: BSI/St. Joe and Santa Fe}

In 1981, the SEC brought two civil enforcement actions alleging insider trading through foreign banks. ${ }^{52}$ The first case filed, BSI/St. Joe, concerned the acquisition of call options and common stock of St. Joe Minerals Corporation ("St. Joe") through Banca Della Svizzera Italiana ("BSI"), prior to the public announcement of a cash tender offer for St. Joe by a subsidiary of Seagram Company Ltd. ("Seagram"). The SEC sought, among other things, a TRO and an asset freeze. ${ }^{53}$ After commencing the injunctive action, the SEC tried unsuccessfully for eight months to determine the names of the BSI customers. Finally, the SEC moved for an order to compel BSI's New York branch to disclose its customers' names. BSI countered that such disclosure would violate Swiss secrecy laws and subject it to civil and criminal liability in Switzerland. ${ }^{54}$

The court granted the SEC's motion and ordered BSI to disclose fully its customers' identities. ${ }^{55}$ Among other things, the court found that BSI had made deliberate use of Swiss non-disclosure laws to evade the U.S. securities laws on insider trading. ${ }^{56}$ The court also noted the overwhelming interest of the United States in this matter, stating:

52. SEC v Banca Della Svizzera Italiana and Certain Purchasers of Call Options for the Common Stock of St. Joe Minerals Corp. ("BSI/St. Joe"), 92 FRD 111 (SD NY 1981); SEC v Certain Unknown Purchasers of the Common Stock of, and Call Options for the Common Stock of, Santa Fe Intl. Corp. ("Santa Fe"), [1983-1984 Transfer Binder] Fed Secur L Rptr (CCH) \ 99,424 (SD NY 1983).

53. BSI/St. Joe, 92 FRD at 113 .

54. Id.

55. Id at 119. Before the court order was signed, BSI obtained a waiver of Swiss secrecy laws from its customers. Id at 113.

56. Id at 118-19. 
The strength of the United States interest in enforcing its securities laws to ensure the integrity of its financial markets cannot seriously be doubted. That interest is being continually thwarted by the use of foreign bank accounts. . . It would be a travesty of justice to permit a foreign company to invade American markets, violate American laws if they were indeed violated, withdraw profits and resist accountability for itself and its principals for the illegality by claiming their anonymity under foreign law. ${ }^{57}$

Based on the U.S. court's discovery decision in BSI/St. Joe, the SEC was able to pursue successfully the foreign purchasers, including both Giuseppe B. Tome, who exploited a confidential relationship with Edgar M. Bronfman, the Chairman and Chief Executive Officer of Seagram's, and Paolo Mario Leati, an Italian broker-dealer who was Tome's tippee. ${ }^{58}$

Within days after it moved to compel disclosure in BSI/St. Joe, the SEC filed the second action, Santa $F e$, an even larger insider trading case involving five of the largest banks in Switzerland. Based on the timing and size of the transaction, the SEC alleged that unknown purchasers had obtained profits of over $\$ 7.8$ million by illegally trading on inside information concerning a takeover of the Santa Fe International Corporation ("Santa Fe") by Kuwait Petroleum Corp. ${ }^{59}$ The filing of Santa Fe, on the heels of precedent-setting $B S I / S t$. Joe, demonstrated that international insider trading cases raising the issue of secrecy laws were not sporadic events. It was thus clear that absent a credible alternative, the SEC would increasingly seek and obtain, by court order if necessary, information identifying the persons who were the beneficial owners of the securities purchased in the United States from the banks acting as agents in the transactions.

\section{B. MOUs}

$B S I / S t$. Joe and Santa Fe provided the SEC and Swiss governmental authorities, as well as the Swiss banks, with the impetus to develop a cooperative mechanism that would address the most urgent problems confronted by the SEC, as well as the concerns and legal constraints existing in Switzerland. ${ }^{60}$ The resulting mechanism, the 1982 MOU with the Swiss, ${ }^{61}$ provided for the establishment of a separate private agreement among members of the Swiss Bankers Association.62 The agreement, known as Convention XVI, provided that, in cases involving takeovers, where insider

57. Id at 117,119 .

58. See $S E C$ v Tome, 638 F Supp 596 (SD NY 1986), aff'd 833 F2d 1081 (2d Cir 1987). See also Michael D. Mann \& Joseph G. Mari, Developments in International Securities Law Enforcement and Regulation 41, 58-70 (Oct 24, 1990) (paper presented at the Securities Regulation Seminar in Los Angeles, California).

59. See Santa $F e$, [1983-1984 Transfer Binder] Fed Secur L Rptr (CCH) ף 99,424.

60. Although the Swiss Treaty was in effect at the time these two cases were brought, see note 29, the Treaty contains a dual criminality requirement. Although provisions of Swiss law contained prohibitions against some forms of insider trading, insider trading did not become illegal in Switzerland until 1988. Thus, the Treaty was not available as an alternative mechanism.

61. MOU between the United States and Switzerland, 43 SEC Docket 141 (Aug 31, 1982).

62. Since insider trading was not illegal per se in Switzerland, and because the MOU was implemented by the private agreement, there was no legal mechanism available for piercing Swiss secrecy law. Accordingly, the Swiss banks obtained express waivers of the secrecy provisions from their customers, conditioned on the terms of the MOU and the private agreement. 
trading was suspected, the signatory banks would disclose and furnish information to the SEC without violating Swiss bank secrecy laws. ${ }^{63}$ Under Convention XVI, a three-member commission appointed by the Swiss authorities would examine the SEC's requests and determine whether the MOU's thresholds were met to warrant release of the information or a freeze of assets. ${ }^{64}$ Thereafter, the information was provided through the Swiss government to the SEC. ${ }^{65}$

While the 1982 MOU with Switzerland was effective in prosecuting insider trading cases involving trading through Swiss banks, its utility was limited since it had been tailored very narrowly to address the particular concerns raised by $B S I / S t$. Joe and Santa $F e$ : insider trading through bank accounts. Based on its experiences under the 1982 Swiss MOU, the SEC sought to develop more comprehensive relationships with other foreign securities authorities. In 1986, the SEC entered into MOUs with regulators representing the world's largest capital markets: the United Kingdom and Japan. 66 Both MOUs established a substantially broader scope of cases for which assistance could be obtained. The MOU with the United Kingdom's Department of Trade and Industry ("DTI"), for example, includes assistance in matters relating to market conduct and investment businesses. In addition to providing assistance in particular cases, the MOUs with the United Kingdom and Japan help to provide a more regular and formal mechanism for communications about all securities matters between the signatories by designating certain contact persons.

The SEC further broadened its approach to MOUs and the effect of MOUs in 1988 with the signing of understandings with securities regulators in three Canadian provinces and Brazil.67 These MOUs were designed to cover virtually all offenses that could occur under the federal securities laws and provide for the fullest degree of assistance possible, including providing access to information in agency files and obtaining documents and testimony.

Until 1988, assistance available under the MOUs was limited to that which could be provided through the best efforts of regulators. At the time, most regulators, including the SEC, were not authorized to use their compulsory

63. Agreement XVI of the Swiss Bankers' Association with regard to the handling of requests for information from the SEC on the subject of misuse of inside information, 43 SEC Docket 155 (July 14, 1982).

64. The MOU with Switzerland established objective standards for transactions and price movements for determining whether its mechanism was available for a particular case.

65. For a more detailed description of Convention XVI, as well as the development of an MOU in 1987 and the exchange of diplomatic notes, see Mann \& Mari, Developments at 58-70 (cited in note 58).

66. MOU on Exchange of Information Between the SEC and the U.K. Department of Trade and Industry ("DTI") in Matters Relating to Securities and Between the U.S. Commodity Futures Trading Commission and the U.K. DTI in Matters Relating to Futures, 43 SEC Docket 176 (Sept 23, 1986); Memorandum of the SEC and the Securities Bureau of the Japanese Ministry of Finance on the Sharing of Information, 43 SEC Docket 184 (May 23, 1986).

67. MOU between the SEC and the Ontario Securities Commission, the Commission des Valeurs Mobilieres du Quebec and the British Columbia Securities Commission, 43 SEC Docket 186 (Jan 7, 1988); MOU between the SEC and the Brazil Comissao de Valores Mobiliarios, 43 SEC Docket 206 (Jan 12, 1990). 
powers to assist foreign authorities. ${ }^{68}$ In 1988, however, Congress authorized the SEC to compel the production of evidence and testimony at the request of a foreign authority, without regard to whether the matter under investigation by that authority would constitute a violation of U.S. securities laws. ${ }^{69}$ At the time the legislation was adopted, Congress clearly envisioned that it would provide a strong incentive for countries to agree to provide the SEC with similar assistance. This goal has been achieved; the granting of this new authority to the SEC, combined with the commitment of the Canadian and Brazilian regulators to provide similar assistance or to seek similar authority, set the course for a new generation of MOUs. Since 1988, numerous countries have enacted similar legislation to allow for the implementation of MOUs that are broad in both scope of cases covered and range of assistance available. ${ }^{70}$

An indication of the growth of international cooperation in light of these, and other, developments has been the increase in the number of requests for assistance made by the SEC to foreign governments, and of requests made to the SEC. ${ }^{71}$ In connection with these requests, the SEC has exercised its

68. For example, $\$ 21$ (a) of the Exchange Act, in its original version, limited the SEC's ability to investigate violations of "this Title." Securities Exchange Act of $1934 \S 21$ (a), 48 Stat 899. The other securities laws contained similar provisions. See Mann \& Mari, Developments at 78, 81 (cited in note 58).

69. See Exchange Act $\$ 21$ (a)(2), 102 Stat at 4677. The SEC obtained the authority necessary to implement fully these agreements under $\S 6$ of the Insider Trading and Securities Fraud Enforcement Act of 1988, which added $\$ 21(\mathrm{a})(2)$ of the Exchange Act. Insider Trading and Securities Fraud Enforcement Act of 1988, Pub L No 100-704, 102 Stat 4677 (1988), codified at 15 USC \& 78u(a) (Supp 1989).

70. See Senate Report on the International Securities Enforcement Cooperation Act of 1988, S Rep No 100-461, 100th Cong, 2d Sess 9 (1988). Since the adoption of $\$ 21(a)(2)$, several other countries have proposed and adopted legislation authorizing the use of compulsory powers at the request of a foreign securities authority. In 1989, the French Law of August 2 was adopted; the COB is now authorized to use compulsory powers on behalf of a foreign securities authority, Law No 89 . 531 8-1, art 12-2 (1989) (Fr). In 1989, the U.K. Companies Act was modified to provide the U.K. Secretary of State for the DTI to assist overseas regulators. 1989 U.K. Companies Act Section 82. The SEC and U.K. authorities entered into an expanded MOU that encompasses the use of these new powers on September 25, 1991. See note 68. In the summer of 1990, the Japanese Diet adopted Section 184-2 of the Securities Exchange Law, which provides that the Minister of Finance of Japan may, at the request of a foreign regulator, use certain compulsory methods to collect and transmit information. Japanese Law Article 184-2 of the Securities and Exchange Law. The law requires, among other things, that such assistance be conditioned upon the availability of reciprocal assistance to Japan. The SEC is also working to expand the SEC-Japan MOU to encompass the use of compulsory measures. See also Kingdom of the Netherlands, Regulation for the Supervision of Trading in Securities (1992).

71. For example, in fiscal year 1989, the SEC "made 101 formal requests to foreign authorities for assistance and received 150 requests from foreign authorities." 1989 SEC Annual Report at 1. In fiscal year 1990, the SEC made over 160 requests to foreign authorities and received a substantial number as well. 1990 SEC Annual Report at 4.

In fiscal year 1990, many SEC insider trading cases involved foreign elements; the SEC has made requests to foreign authorities in connection with these cases. See, for example, Finacor Anstalt, [1991 Transfer Binder] Fed Secur L Rptr (CCH) ף 96,272 (SD NY 1991); Fondation Hai, 736 F Supp 465; Heider, [1990-1991 Transfer Binder] Fed Secur L Rptr (CCH) ף 95,651 (SD NY 1990). In Finacor Anstalt, the SEC instituted actions against individuals who allegedly earned $\$ 3$ million in insider trading profits through institutions in Liechtenstein, Luxembourg, and the Cayman Islands. Penny stock cases also have international dimensions. For example, in 1989, the SEC brought an action against Arnold Kimmes, who, together with certain confederates, conducted offerings in 
powers under Section 21(a)(2) on behalf of several foreign securities authorities. Similarly, pursuant to requests from the SEC, foreign securities authorities have used their compulsory powers on behalf of the SEC. In response to the success of information-sharing MOUs (as demonstrated by the successful prosecution of securities cases with international elements) as well as the role of MOUs as foundations for harmonization and mutual recognition initiatives, more and more securities authorities are entering into MOUs with the SEC. 72

\section{MOUs as an Analogy for Cooperation in Enforcing Judgments and Provisional Measures}

The SEC's experience with MOUs provides an important analogy when fashioning a mechanism for blocking and obtaining illicit gains, especially in light of the many benefits to MOUs. The MOU approach has proven itself an effective means for enhancing the SEC's evidence gathering ability for a variety of reasons:

MOUs generally are negotiated with counterparties with direct responsibility for regulating and administering domestic securities markets. As a result, requests made under MOUs can be executed by parties with expertise in securities matters, and who have an ongoing working relationship with the SEC on securities matters generally.

numerous penny stocks and manipulated the aftermarket for such stocks. This group defrauded investors in the United States, France, Switzerland, and other countries out of millions of dollars. SEC v Kimmes, 89 Civ 5942 (ND Ill 1989). See also SEC v International Swiss Investments Corp., Litigation Rel No 11704 [1989 Transfer Binder] Fed Secur L Rptr (CCH) \ 93,710 (WD Wash 1988), aff'd [1989-1990 Transfer Binder] Fed Secur L Rptr (CCH) ף 94,926 (9th Cir 1990).

72. To date, the SEC has entered into 14 agreements or communiques on the exchange of information. See MOU between the United States and Switzerland, 43 SEC Docket 141 (Aug 31, 1982); Memorandum of the SEC and the Securities Bureau of the Japanese Ministry of Finance on the Sharing of Information, 43 SEC Docket 184 (May 23, 1986); MOU on Exchange of Information between the SEC and the U.K. DTI in matters relating to Securities and between the U.S. Commodities Futures Trading Commission and the U.K. DTI in matters relating to Futures, 43 SEC Docket 176 (Sept 23, 1986); MOU between the SEC and the Ontario Securities Commission, the Commission des Valeurs Mobilieres du Quebec and the British Columbia Securities Commission, 43 SEC Docket 186 (Jan 7, 1988); MOU between the SEC and the Brazil Comissao de Valores Mobiliarios, 43 SEC Docket 206 (July 1, 1988); Communique on Exchange of Information between the $S E C$ and the Commissione Nazionale per Le Societa e la Borsa ("CONSOB") of Italy, 44 SEC Docket 1319 (Sept 26, 1989); Agreement Between the United States and the Kingdom of the Netherlands on Mutual Administrative Assistance in the Exchange of Information in Securities Matters, 45 SEC Docket 715 (Jan 12, 1990); Administrative Agreement between the SEC and the Republique Francaise, Commission des Operations de Bourse, 45 SEC Docket 726 (Jan 12, 1990); MOU between the SEC and the Comision Nacional de Valores of Mexico on Consultation, Technical Assistance, and Mutual Assistance for the Exchange of Information, 47 SEC Docket 716 (Oct 18, 1990); Communique on the Exchange of Information and the Establishment of a Framework for Cooperation between the SEC and the Swedish Bank Inspection Board, 49 SEC Docket 472 (June 27, 1991); $M O U$ between the SEC and the Norway Banking, Insurance and Securities Commission Concerning Consultation and Cooperation in the Administration and Enforcement of Securities Laws, 49 SEC Docket 1462 (Sept 30, 1991); Communique between the SEC and the Costa Rican Comision Nacional De Valores on the Provision of Technical Assistance for the Development of the Costa Rican Securities Markets, the Exchange of Information, and the Establishment of a Framework for Cooperation, 49 SEC Docket 1644 (Oct 16, 1991); MOU between the SEC and the Comision Nacional De Valores of Argentina on Consultation, Technical Assistance, and Mutual Assistance for the Exchange of Information, 50 SEC Docket 674 (Dec 18, 1991); MOU between the SEC and the Comision Nacional del Mercado de Valores of Spain Concerning Consultation and Cooperation in the Administration and Enforcement of Securities Laws (July 8, 1992). 
MOUs are non-binding statements of intent that are implemented by generic domestic legislation. As a result, a formula for MOUs can be developed that is consistent with the legislation, and then MOUs can be negotiated with all willing regulators.

MOUs can be negotiated to reflect the full extent to which each authority is willing and able to assist the other pursuant to domestic law. For example, the U.K. MOU, as well as those of other countries, takes into account the jurisdictional differences between securities authorities in foreign countries.

MOUs provide authorities with predictability regarding the scope of assistance available, and the manner in which assistance will be provided. While unilateral measures such as court-ordered extraterritorial measures can be effective, they are subject to a caseby-case review by a court.

The SEC and its foreign counterparts have developed MOUs based on their recognition that they must be able to investigate effectively matters involving foreign conduct to enforce domestic securities laws. In the area of enforcement of judgments, the United States, the United Kingdom, and Japan have already expressed the view that means should be developed to enhance cooperation. ${ }^{73}$ The MOU approach, implemented by legislation, may well provide a viable method for achieving this end.

\section{IV}

\section{INTERNATIONAL MEChaNiSMS FOR ENFORCING JUdGMENTS}

The development of international mechanisms for the enforcement of judgments has already begun. These mechanisms involve drug trafficking and money laundering, areas in which there is a well developed international view that every country must assist in efforts to seize the fruits of these areas of crime. ${ }^{74}$ Moreover, as the European Community legal systems begin to integrate, efforts are being made to remove existing impediments to the execution of judgments.

That these mechanism have already been put into place proves that domestic authorities are willing to consider taking the steps necessary to assist foreign authorities and that international agreements on enforcing judgments and provisional measures can be negotiated and implemented. The approach

73. Trilateral Communique on Cooperation between the SEC, the DTI and the SIB of the United Kingdom, and the Securities Bureau of the Ministry of Finance of Japan, 47 SEC Docket 373 (Oct 1, 1990).

74. There also are conventions on the enforcement of arbitral awards. See Convention on the Recognition and Enforcement of Foreign Arbitral Awards, [1970] 21 UST 2517, TIAS No 6997 (1958). Although there is also a Hague Convention on the recognition and enforcement of foreign judgments, it has not been widely adopted. See The Hague Conference on Private International Law: Convention on the Recognition and Enforcement of Foreign Judgments, 5 ILM 636 (1966) (reproduced from the Final Act, dated April 26, 1966, of the Extraordinary Session of the Hague Conference on Private International Law); Arthur T. von Mehren \& Kurt H. Nadlemann, The Extraordinary Session of The Hague Conference on Private International Law 1966, 15 Am J Comp L 361 (1967). 
taken in the agreements discussed below and the legislation that implements them provide useful models and experience for considering whether and how to create a framework for executing provisional and final judgments in securities cases. Moreover, as discussed herein, experience under the EC Convention shows that courts have effectively utilized the authority granted to them to address problems similar to those confronted by the SEC. Renewed U.S. interest in a convention on the enforcement of judgments was the subject of a study group meeting at the U.S. State Department. On September 2, 1992, the study group discussed a U.S. proposal that the Hague Conference on Private International Law consider the preparation of a new convention on the recognition and enforcement of judgments. ${ }^{75}$

\section{A. The Vienna Convention}

The United Nations Convention Against the Illicit Traffic in Narcotic Drugs and Psychotropic Substances ("Vienna Convention") provides a mechanism for giving effect to foreign judgments in matters relating to drug trafficking offenses. ${ }^{76}$ In 1990, the United States became a party to the Vienna Convention; as of late 1991, fifty-six countries have ratified the convention. The Vienna Convention creates "a comprehensive domestic and international [forfeiture] regime" 77 by, among other things, requiring that each party enact domestic laws to enable it to identify, trace, and freeze property derived from, or used in, drug trafficking and money laundering offenses. Article 5(4) of the Convention specifically provides that parties assist one another in the confiscation of proceeds or properties of such offenses. ${ }^{78}$ This provision of the Convention is unusual since countries usually do not enforce the penal laws of other countries. ${ }^{79}$

The Convention provides for two distinct methods for providing assistance in enforcing judgments. The first is through the initiation of a forfeiture proceeding in the jurisdiction of the requested party based on information provided by the requesting party. ${ }^{80}$ The second method is that the requested party may, in essence, give full faith and credit to a forfeiture

75. Secretary of State's Advisory Committee on Private International Law; Study Group on Judgments; Meeting, 57 Fed Reg 35867-904 (1992).

76. 28 ILM 493 (1989). In addition, the Council of Europe Convention on Laundering, Search, Seizure and Confiscation of the Proceeds from Crime, 30 ILM 148 (1991) (Strasbourg Nov 8, 1990), provides that the signatories will assist in giving effect to foreign judgments, including the institution of provisional measures, for freezing assets from crime that at a later stage may be the subject of a request for confiscation.

77. See Juan C. Marrero, Linda M. Samuel \& Mary B. Troland, An Introduction to International Forfeiture 17 (Dept of Justice, Sept 1991).

78. Article 5(4)(a) provides that, following a request by another party with jurisdiction over specific offenses, a party in whose territory proceeds, property, or instrumentalities are situated shall

(i) submit the request to its competent authorities for the purpose of obtaining an order of confiscation and, if such order is granted, give effect to it; or

(ii) submit to its competent authorities, with a view to giving effect to it to the extent requested, an order of confiscation issued by the requesting Party . . in so far as it relates to proceeds, property, instrumentalities ... situated in the territory of the requested Party.

79. See Restatement (Third) of Foreign Relations Law of the United States $\$ 482$ (1987).

80. Vienna Convention, art $5(4)(\mathrm{a})(\mathrm{i})$. 
order entered in the requesting authority. ${ }^{81}$ The alternatives were provided to accommodate different legal systems. For example, in some countries, such as the United States, it is not possible to enforce a foreign criminal judgment of forfeiture, but one can proceed in rem against proceeds of certain crimes if a factual basis is provided to establish that the property constitutes proceeds of drug trafficking offenses. ${ }^{82}$

In the United States, article $5(4)(a)(i)$ of the Vienna Convention is implemented in part by section $981(\mathrm{a})(1)(B) .83$ This section authorizes, through civil proceedings, the seizure and forfeiture of assets in the United States that represent proceeds of drug-related crimes committed abroad. Its effect is to ensure that tainted assets cannot be protected from seizure by simply moving them to the United States. Among other things, this section provides for civil forfeiture of property found in the United States that is derived from or traceable to a violation of foreign law involving the manufacture, importation, sale, or distribution of a controlled substance, without regard to whether a U.S. law is violated.

Under the U.S. statute, a certified copy of a foreign forfeiture order or judgment encompassing the property is admissible and constitutes probable cause in a civil forfeiture action brought in the United States. ${ }^{84}$ In addition, a certified foreign judgment or conviction for a felony offense relating to controlled substances is admissible into evidence and creates a rebuttable presumption that the activity giving rise to the forfeiture has occurred ${ }^{85}$ This section also provides for the sharing of proceeds with a foreign country that participated directly or indirectly in efforts that resulted in the seizure and forfeiture of property.

\section{B. Mutual Legal Assistance Treaties}

Several mutual legal assistance treaties ("MLATs") also provide that one country may request another, consistent with the requested country's domestic law, to (1) freeze forfeitable assets; (2) initiate a forfeiture action against property; (3) repatriate assets located abroad; and (4) enforce

81. Id at art $5(4)(a)($ ii).

82. Marrero, Samuel \& Troland, Introduction to International Forfeiture at 19 (cited in note 77).

83. 18 USC $\$ 981$ (Supp 1989). This section was originally enacted as $\S 1366$ (a) of the AntiDrug Abuse Act of 1986, Pub L No 99-570, and amended as part of the Anti-Abuse Act of 1988. Section 981 (a) (1) contains three subsections for the forfeiture of (a) assets traceable to, or involved in, money laundering violations; (b) proceeds of foreign drug felonies; and (c) property constituting, or derived from, proceeds traceable to a violation of the Financial Institution Reform, Recovery, and Enforcement Act of 1989 ("FIRREA"), Pub L No 101-73, 103 Stat 183 (1989). It has been proposed that the civil forfeiture provisions be expanded to include the proceeds of foreign kidnappings, robberies, and extortions. See Money Laundering Improvements Act of 1991, S 1665, 102d Cong, lst Sess (Aug 2, 1991).

84. See 18 USC $\$ 981(\mathrm{i})(3)$ (certified copy of foreign forfeiture order or judgment encompassing subject property admissible and "shall constitute probable cause" in civil forfeiture action against such property).

85. Id. 
forfeiture judgments issued by a foreign court. $^{86}$ Through the U.S. Department of Justice, the SEC has used mutual legal assistance treaties to obtain provisional freezes of assets that it suspected were obtained in violation of U.S. federal securities laws. ${ }^{87}$ Indeed, the willingness of the Swiss authorities to provide assistance has proven crucial to the SEC's success in precluding the dissipation of assets pending a final judgment, and thus in safeguarding the funds for possible return to defrauded investors. The Treaty does not cover the return of assets to defrauded investors - only assets belonging to the requesting state. A Swiss magistrate, however, determined that such proceeds could be returned to U.S. investors ${ }^{88}$ pursuant to Article 74 of the Swiss federal law on international legal assistance in criminal matters of March 20, 1981.89 This was an unprecedented ruling; it opened the possibility of expanding current thinking about mutual assistance legislation to cover this very important topic. It also highlights that, absent such a creative approach, neither MLATs nor existing mutual legal assistance legislation provide a certain or fully satisfactory mechanism for enforcing judgments to ensure the return of funds to defrauded investors in the U.S.

\section{European Convention}

The European Convention on Jurisdiction and Enforcement of Judgments in Civil and Commercial Matters ("EC Convention") was adopted to facilitate

86. For example, in 1988, the United States and the United Kingdom entered into an agreement relating to drug trafficking that specifically provided for assistance in freezing and forfeiting the proceeds and instrumentalities of drug trafficking. See Agreement Between the Government of the United States of America and the Government of the United Kingdom of Great Britain and Northern Ireland Concerning the Investigation of Drug Trafficking Offenses and the Seizure and Forfeiture of Proceeds and Instrumentalities of Drug Trafficking [entry in force 1990]. See also The Drug Trafficking Offenses Act and Criminal Justice Act 1988 (permitting enforcement of confiscation orders) and The Criminal Justice (International Cooperation) Act 1990.

87. The SEC has the means to request, through the U.S. Department of Justice, that assets be frozen pursuant to criminal mutual legal assistance treaties. See, for example, Treaty on Mutual Assistance in Criminal Matters between the United States and Switzerland (cited in note 29). See also SEC v Dennis Levine, Diamond Holdings, S.A. International Gold, Inc. and Bernhard Meier, 86 Civ 3726 (SD NY 1986); SEC v BSI and Certain Unknown Purchasers of Call Options for the Common Stock of St. Joe Minerals Corp., 81 Civ 1836 (SD NY 1981).

88. The underlying U.S. case, SEC v Eurobond Exchange Ltd. et al., Civil Case No 90-378 DT (CD Cal), concerned, among other things, the fraudulent sale to the public of over $\$ 1$ million of unregistered securities, the proceeds of which are frozen in Switzerland. The securities were offered by Gerald Leo Rogers, who made misrepresentations to investors about the use of the proceeds of the sale of securities.

89. In his ruling the magistrate noted that the return of these proceeds was not required under Swiss law but was discretionary based upon an examination of each case. One factor that the court considered was the likelihood that the funds were the proceeds of the crime. In addition, the magistrate considered whether: Rogers had the proceeds at his legal or actual disposal; in Switzerland there were any rights of third parties that would bar the return of the monies; the requesting state accords a corresponding right; and, guarantees are provided that the fate of the assets would be determined in accordance with the principles of the European convention on the protection of human rights and basic freedoms of November 4, 1950. See Order dated July 11, 1992, Office of the Prosecuting Attorney IV for the Canton of Zurich, Office 2, Peter Cosandey, Attorney.

A previous attempt by the U.S. court-appointed trustee/receiver to secure the frozen funds through proceedings before a cantonal court in Zurich had been unsuccessful. 
further the unification and integration of European Community legal systems. ${ }^{90}$ The EC Convention provides a model for assistance in executing all types of judgments for both final relief and provisional relief in civil matters. ${ }^{91}$ Cases considered under the EC Convention further exemplify the potential effectiveness that an understanding on execution of judgments could provide. ${ }^{92}$ In particular, in Republic of Haiti $v$. Duvalier, ${ }^{93}$ Haiti instituted an action in France to recover money allegedly embezzled by members of the former president's family who resided in France. The plaintiffs discovered that the defendants were using a U.K. law firm to invest assets abroad, and applied to the U.K. courts for a Mareva injunction, as well as an order requiring the law firm to identify assets belonging to the defendants that had not been identified in the French proceeding. The U.K. court determined that there was sufficient evidence that the plaintiffs had a "good arguable case," and that there was evidence that the Duvalier family was secreting

90. In 1988, the Parallel Convention on Jurisdiction and the Enforcement of Judgments in Civil and Commercial Matters ("The Lugano Convention") was adopted in Lugano, Switzerland. It is in force between France, Luxembourg, Portugal, the United Kingdom, and Switzerland.

The United States and the United Kingdom negotiated a draft convention on the enforcement of judgments in the late $1970 \mathrm{~s}$. One purpose of the draft convention was to limit the applicability of the EC Convention to U.S. persons and entities. It was never signed, primarily because the United Kingdom insurance industry, among others, strongly opposed the Convention due to concerns about the potential for products liability claims against exporters. In addition, concerns were raised regarding recognition of multiple damages in antitrust actions. See P. M. North, The Draft U.K./U.S. Judgments Convention: A British Viewpoint, 1 Nw J Intl L Bus 219 (1979); Peter Hay \& Robert J. Walker, The Proposed Recognition-of-Judgments Convention Between the United States and the United Kingdom, 11 Tex Intl L J 421 (1976); Hans Smit, The Proposed United States-United Kingdom Convention On Recognition and Enforcement of Judgments: A Prototype for the Future?, 17 Va J Intl L 443 (1977).

91. All 12 member states are parties to the Brussels Convention but not all are parties to the conventions as amended by the Spanish-Portuguese accession. Article 24 of the EC Convention states that "Application may be made to the courts of a Contracting State for such provisional, including protective, measures as may be available under the law of that State ...."

In addition, the Council of Europe: European Convention on Certain International Aspects of Bankruptcy, (30 ILM 165 (1991)), provides that bankruptcy liquidators may seek the assistance of authorities in other countries for provisional measures.

92. In the U.K. Civil Jurisdiction and Judgments Act 1982, the United Kingdom acceded to the EC Convention, including article 24 , see footnote 74 . Prior to that time, a U.K. court would not have had jurisdiction to grant a Mareva injunction to preserve assets in the United Kingdom, while the subject matter of the action proceeded abroad. Under the legislation, a U.K. court has the power to grant interim relief where proceedings are within the scope of the EC Convention and a foreign proceeding has been or is about to be commenced. This power can be extended to cases from other countries by "Order of Council".

In Denilauler v S.n.c. Couchet Freres, [1980] ECR 1553, [1981] 1 CMLR 62, the EC court construed article 24. In considering the question of whether articles $27(2)$ (default judgments not recognized if defendant not provided sufficient notice) and 46(2) (requiring proof of service) applied to proceedings in which provisional measures are taken without the defendant being heard, the court held that the enforcement provisions of the EC Convention did not apply to ex parte provisional orders.

The court recognized that the beneficial "surprise" effect of provisional measures would be largely lost if service were required in order for provisional measures to be enforced pursuant to the EC Convention. The court also stated, however, that article 24 would still permit any party to apply to the courts of a contracting State for such provisional or protective measures as may be available under the law of the enforcing State.

Commentators have stated that, by implication, Mareva injunctions with extraterritorial effect can be provisionally enforced under the EC Convention, provided that the defendant is notified and has an opportunity to oppose the order. See Collins, $105 \mathrm{~L} \mathrm{Q} \mathrm{Rev} \mathrm{at} \mathrm{292-94} \mathrm{(cited} \mathrm{in} \mathrm{note} \mathrm{43).}$

93. [1989] 2 WLR 261. 
assets in foreign jurisdictions in a deliberate attempt to move the assets from the court's jurisdiction. Even though the defendants were outside of the U.K. court's jurisdiction, it issued a Mareva injunction in aid of the proceedings in France. The order restrained the defendants and the U.K. solicitors from dealing with the proceeds identified in the French complaint, and other assets wherever located. ${ }^{94}$ The defendants were also ordered to disclose the value of the assets. In upholding the order, the appeals court stated that, in light of the plain and admitted intention of the defendants to move their assets out of the reach of the law, coupled with the resources they have obtained and the skill they had shown in doing so (citing to a prior Mareva case), "some situations . . . cry out-as a matter of justice to the plaintiffs-for disclosure orders and Mareva-type injunctions covering the foreign assets of defendants even before judgment." 95

\section{Model for Assistance in ENForcing JUdGments in SeCURITIES MatTers}

A. MOUs

By melding the approaches taken in the Vienna and the EC Conventions with the SEC's approach to MOUs, it may be possible to develop an effective alternative that could achieve the same results as the unilateral actions taken in Wang and Lee and Pantell and provide a more comprehensive approach to enforcing judgments than that used in Antar. The resulting agreements would address the concerns raised about the extraterritorial reach of foreign courts $^{96}$ and reduce the potential for conflict between court decisions rendered in more than one jurisdiction as to the status of assets maintained by third parties on behalf of defendants. Finally, an internationally acceptable approach would minimize uncertainties in the international banking system about the potential for double liability that might be created by conflicting legal obligations. ${ }^{97}$ Such an approach may also reduce the timing problems confronted in Fondation Hai.

Applying the MOU approach in the area of enforcing provisional orders and final judgments would offer many of the same benefits as MOUs for the exchange of information. For example, MOUs for assistance in enforcing judgments would be negotiated and administered by the authorities with

94. Collins, $105 \mathrm{~L} Q \mathrm{Rev}$ at 285 (cited in note 43).

95. Republic of Haiti v. Duvalier, [1989] 2 WLR 261, 273 (citing Babanaft Intl. Co. S.A. v Bassatne, [1989] 2 WLR 232, 247).

96. See, for example, Comment, SEC v. Standard Chartered Bank: Maintaining the Integrity of U.S. Capital Markets or Extraterritoriality Run Rampant, 22 L \& Policy in Intl Bus 159 (1991) (authored by Susan R. Essex).

97. For example, in Wang and Lee, SCB argued that it was subject to potential double liability if the U.S. court required it to pay funds in the United States and the Hong Kong court also ordered it to pay the money to Lee. Under the proposal described herein, it would be possible to avoid this potential dilemma by having the foreign bank be subject to a consistent order in the jurisdiction where the funds are maintained. 
direct responsibility for initiating actions in domestic courts to enforce securities laws. Therefore, the authorities providing the assistance would be experienced in enforcing securities judgments and obtaining provisional measures from the relevant courts or authorities. Moreover, the parties to such an MOU would fashion agreements that bridge the differences in how such relief may be obtained under different legal systems. Finally, if the MOUs are negotiated on a bilateral basis, as are the MOUs on information sharing, it is likely that they can be negotiated more quickly than treaties or multilateral conventions such as the Vienna or EC Conventions.

As discussed in more detail below, an MOU on enforcement of judgments would, among other things, (1) identify the scope of assistance that would be available, as well as the types of cases covered; (2) establish procedures for seeking assistance under the MOU; and (3) set forth any limitations on the ability of an authority to provide such assistance.

1. The Scope of Assistance That Would Be Available. The remedies available to securities regulators will differ from country to country. At the outset, it will therefore be critical for the MOU to identify with particularity the types of remedies that could be provided. The logical starting point would be to include assistance for cases involving provisional measures or final judgments that serve to deprive wrongdoers of the profits of their illegal activity, and for the recovery of funds for return to defrauded investors. This approach would address the problems raised in Wang and Lee, Unifund, and Antar.

Given the differences in statutory schemes for regulating securities, it will be critical for the MOU to identify the range of securities matters for which assistance will be available. It is expected that, at a minimum, such an agreement would cover cases involving fraud. ${ }^{98}$ Even though there may not be international unanimity about enforcement cases involving more technical issues such as disclosure and reporting requirements, there is general willingness to interdict fraud. Optimally, MOUs that cover a full range of securities matters could be negotiated.

2. The Procedures for Seeking Assistance Under the MOU. As noted in Part IV above, under certain circumstances, courts in the United States and elsewhere already recognize and enforce foreign judgements. The value of the MOU would be to provide a direct and credible avenue for access to the courts or other appropriate tribunals to facilitate the execution of requests in an effective, uniform, and timely manner.

The MOU would provide specific procedures for an authority to follow when seeking to have a provisional order or final judgment executed in the

98. It is not anticipated that the MOU would encompass enforcement of penalties since currently many countries, including the United States, generally will not enforce the penal judgments of other countries. Thus, concerns about assessing the fairness and proportionality of a penalty imposed by a foreign court before enforcing such a penalty can be avoided. In some areas, however, consensus is being reached that, to fully combat crime, recognition may be given to penal judgments of a particular class, such as with the Vienna Convention. 
legal system of the other authority. It is anticipated that the MOU would be available, for example, where the SEC brought an action in a U.S. court alleging violations of the federal securities laws seeking either a provisional order blocking or freezing alleged illicit profits, wherever in the world they may be located, or a final judgment for permanent relief. After a hearing or trial, the U.S. judge would rule on the substantive question of whether the facts before it supported granting the requested relief.

While the U.S. court's order could theoretically be enforced directly with respect to funds within its jurisdiction, in reality, enforcement is difficult when third parties maintain assets on behalf of defendants that are physically located outside the United States. Similar difficulties occur when, as in Wang and Lee and Antar, defendants within the U.S. court's personal jurisdiction refuse to abide by orders relating to assets located outside the United States. In such cases, the SEC would request assistance from a foreign securities authority. The SEC would provide the foreign authority with certified documentation of the U.S. court's order, similar to that required by the Vienna Convention, ${ }^{99}$ as well as an affidavit or other information demonstrating that some, or perhaps all, of the illegally obtained assets were located within the foreign jurisdiction. Upon receipt of the request, the certified documentation of the order, and evidence that assets related to the matter were located in its country, the foreign authority, pursuant to both the MOU and domestic law, would petition its courts or proper authorities for relief on behalf of the SEC. ${ }^{100}$

3. Limitations on the Ability to Provide Assistance. Consistent with U.S. law, the MOU would need to incorporate clearly traditional grounds for not recognizing judgments. For example, assistance could be refused in instances where the court of origin lacked jurisdiction over the matter, there was fraud involved in securing the foreign order, enforcement of the foreign order would be contrary to domestic public policy, or the foreign judgment was rendered under a system that did not provide procedures compatible with due process of law. ${ }^{101}$

\section{B. U.S. Legislative Considerations}

The premise of any MOU on the enforcement of provisional measures and final judgments would be the mutual enforceability of provisional orders and final judgments that fall within the scope of the MOU. While courts in the United States recognize and enforce foreign judgments, this practice has

99. See notes 76-84 and accompanying text.

100. It would be anticipated that a similar procedure would be followed for requests for assistance by a foreign authority to the SEC.

101. See Restatement (Third) of Foreign Relations Law of the United States $\$ 482$; Uniform Foreign Money Judgments Recognition Act, 13 ULA $261 \S 4$ (1986); Hilton v Guyot, 159 US 113 (1895). It is unlikely, however, that the SEC or any other regulator would enter into an MOU with a regulator whose national legal system did not provide sufficient procedural and substantive rights. 
developed through a case-by-case approach. ${ }^{102}$ Thus, while it might be possible to rely on the current method, the enactment of legislation that expressly provides the necessary foundation for such action should be considered. The SEC has recently informed Congress of its intention to consider such an approach. ${ }^{103}$

A legislative approach would follow current practice and thus would not introduce new concepts into a court's consideration of whether to enforce a foreign judgment. Rather, it would help lay the legal foundation for a U.S. court to receive and effectuate a foreign securities judgment or provisional measure obtained by a foreign securities authority. It would thus incorporate well-established grounds under U.S. law for the recognition and enforcement of foreign judgments. For example, in Hilton $v$. Guyot, ${ }^{104}$ the Supreme Court established a general rule favoring the recognition and enforcement of foreign judgments without reexamination of the merits of the dispute. ${ }^{105}$ These standards have been incorporated into the Uniform Money Judgments Recognition Act, which has been adopted by sixteen states. ${ }^{106}$

The implementation of MOUs through legislation would provide certainty as to the governing procedure, as well as to the types and extent of relief available. In addition, it would provide a model for foreign authorities to follow. Its procedures would be crafted in a manner that would create a mechanism responsive to U.S. concerns and thus, if duplicated abroad, would ensure that reciprocal assistance would be available. ${ }^{107}$ Most importantly, a

102. Although the United States "is among the most receptive nations with regard to recognition and enforcement of foreign country judgments," unlike sister state judgments, foreign country judgments are not governed by the full faith and credit clause of the U.S. Constitution. As a result, the recognition and enforcement of foreign judgments is governed by state common law. Andreas $F$. Lowenfeld, United States of America, in Platto, ed, Enforcement of Foreign Judgments Worldwide 259 (cited in note 10); Gary B. Born \& David Westin, International Civil Litigation in United States Courts 563-64 (Kluwer, 1989); von Mehren, 17 Va J Intl L at 402 (cited in note 4).

103. See SEC Authorization for Appropriations for Fiscal Year 1992-1994, dated April 1991.

104. 159 US 113 (1895).

105. The Court stressed that retrying foreign cases was not favored:

[W] here there has been opportunity for a full and fair trial abroad before a court of competent jurisdiction, conducting the trial upon regular proceedings, after due citation or voluntary appearance of the defendant, and under a system of jurisprudence likely to secure an impartial administration of justice between the citizens of its own country and those of other countries, and there is nothing to show either prejudice in the court, or in the system of laws under which it was sitting, or fraud in procuring the judgment, or any other special reason why the comity of this nation should not allow it full effect, the merits of the case should not, in an action brought in this country upon the judgment, be tried afresh, as on a new trial or an appeal, upon the mere assertion by the party that the judgment was erroneous in law or in fact.

Hilton $v$ Guyot, 159 US at 202-03.

106. With respect to reciprocity, as with Exchange Act $\$ 21(a)(2)$, legislation might contain requirements that the SEC consider the availability of reciprocal assistance, as well as the U.S. public interest, in deciding whether to assist a foreign securities authority in enforcing a judgment in the United States.

107. Implementing legislation also may delineate procedures for granting a request to enforce a final judgment. The procedural aspects of such requests, which could be very similar to those used in purely domestic cases. See, for example, FRCP 65. For example, the SEC, acting on behalf of the foreign securities authority, could appear in the U.S. court to present the judgment or order. If emergency relief is sought on the basis of a foreign finding that the fruits of illegal securities activity 
legislative approach would create uniform protections to be utilized by U.S. courts to insure against abuse of the system. ${ }^{108}$

\section{VI}

\section{Conclusion}

Maintaining the integrity of international markets requires effective enforcement. Accordingly, regulators must continue to develop the means to catch, prosecute, and deter those who commit fraud. Depriving those wrongdoers of their illicit profits is not only a powerful deterrent, but also has the added benefit of compensating the victims of fraud. As with mechanisms for information sharing, there would be significant and tangible benefits to developing agreements on the enforcement of provisional orders and final judgments. Such agreements would avoid jurisdictional confrontations caused by the need to take unilateral measures, and maximize the opportunities to take the profit out of crime. The end result would be to strengthen the international securities markets by increasing investor confidence in those markets.

may otherwise be dissipated, the U.S. court, as in a purely domestic matter, could issue an ex parte order for a ten day duration, at the conclusion of which the SEC and the defendants would have an opportunity to appear and argue the question of whether a preliminary judgment should issue. Such assistance could be available, for example, where (1) the foreign court has issued an order in such action to preserve the availability of assets or property or other similar relief for purposes of securing satisfaction of a future judgment for equitable or legal relief; and (2) there is a reasonable basis for concluding that the failure to grant such an order could result in assets or property being removed from the court's jurisdiction, dissipated, or conveyed to another person, or could otherwise impair the ability of the foreign securities authority or court to enforce a future judgment.

108. A central concern when considering potential legislation for effectuating foreign provisional orders and final judgments is ensuring that the fairness of the domestic legal systems are not compromised. In this regard, it may be beneficial for the legislation to authorize the U.S. court to evaluate whether findings by the foreign court or tribunal were based on full and fair consideration of the facts and were consistent with traditional standards. However, consistent with the approach taken in Hilton $v$ Guyot, in enforcing foreign provisional orders and final judgments, it is important that the findings of a foreign court that meet the necessary criteria for enforcement are accepted without the enforcing court "looking behind" the foreign order to consider independently the case as a whole. It must recognize that a foreign regulatory or prosecutorial body with jurisdiction over a matter often must draw facts from many disparate sources; those facts are then weighed against the law of the jurisdiction by a local court according to its legal precedents and procedures. The provisional order or final judgment is then issued pursuant to those legal standards.

In another context, Congress authorized the SEC to act based on findings by a foreign court or foreign securities authority. In the Securities Acts Amendments of 1990, the SEC was authorized to institute administrative proceedings against a securities professional whom a foreign authority has found to have violated foreign laws substantially similar to those of the United States. The purpose of the proceedings are to determine if the securities professional should be precluded from conducting unrestricted operations in the U.S. securities markets. See 1990 Exchange Act $\$ 15(b)(4)(G), 104$ Stat 2715. 